Acta Universitatis Wratislaviensis No 3705

PRAWO CCCXX

Wrocław 2016

DOI: $10.19195 / 0524-4544.320 .5$

\author{
EWA MATLOCHOVÁ
}

Uniwersytet Wrocławski

e-mail: EwaMatloch@seznam.cz

\title{
Dostosowanie prawa wewnętrznego w Republice Czeskiej do unijnych wymogów antydyskryminacyjnych na przykładzie prawa pracy
}

\section{Wstęp}

Unia Europejska przez dziesięciolecia skupiała się na zwalczaniu dyskryminacji ze względu na narodowość lub płeć celem zbudowania silnego rynku wewnętrznego. W 2000 roku, aby w nowym tysiącleciu skupić się na podstawowych wartościach konstytucyjnych, powstało nowe antydyskryminacyjne prawo unijne zakazujące dyskryminacji ze względu na nowe czynniki. Nowe unijne prawo antydyskryminacyjne, które przybrało zwłaszcza formę dyrektyw antydyskryminacyjnych, zostało wprowadzone do porządków prawnych państw członkowskich i obecnie zapewnia efektywną ochronę dla osób fizycznych i określonych grup, które są narażone na dyskryminację ${ }^{1}$. Dostosowanie prawa wewnętrzego do wymogów unijnych przybrało różne formy oraz napotkało różne trudności w państwach członkowkich. W artykule zostanie przedstawiony dorobek prawa unijnego z zakresu dyskryminacji łącznie z ogólnie przedstawionym orzecznictwem Trybunału Sprawiedliwości UE na temat zasady równości oraz opisane zostanie wdrożenie tej zasady do prawa wewnętrznego Republiki Czeskiej.

${ }^{1}$ L. Farkas, European Commision, Directorate-General for Justice, How to Present a Discrimination Claim: Handbook on seeking remedies under the EU Non-discrimination Directives, UE 2011, s. 5 


\section{Zasada równości w prawie pierwotnym UE i jej obowiązywanie w Republice Czeskiej}

Zwalczanie dyskryminacji ze względu na przynależność państwową jest jednym z podstawowych celów Unii Europejskiej, dyskryminacja ta jest zakazana według traktatów założycielskich ${ }^{2}$. Dodatkowo Unia Europejska zwalcza dyskryminację ze względu na inne podstawy — pochodzenie, rasę, płeć, religię, stan zdrowia, orientację seksualną, wiek. Prawo do niedyskryminacji zostało również wzmocnione Kartą Praw Podstawowych (dalej - Karta ${ }^{3}$ ), która na podstawie traktatu z Lizbony ${ }^{4}$ dołączyła do prawa pierwotnego UE i stała się prawnie wiążącą. Karta ta nie rozszerza kompetencji UE, które zostały określone w traktatach założycielskich, ale ustala szereg norm powołanych przez Trybunał Sprawiedliwości UE. Obowiązek działania zgodnie z Kartą mają nie tylko instytucje unijne, ale również państwa członkowskie w zakresie stosowania prawa UE (art. 51 ust. 1 Karty $)^{5}$.

Republika Czeska jako państwo członkowskie UE związana jest prawem pierwotnym oraz wtórnym UE, jednak w trakcie ratyfikacji Traktatu z Lizbony postanowiła dołączyć do protokołu nr 30 traktatu lizbońskiego. Jednak protokół stosowania Karty Praw Podstawowych wobec Republiki Czeskiej (dalej RCZ), zwany także nie do końca poprawnie „czeskim protokołem” albo „wyjątkiem Václava Klausa”, wydaje się obecnie sprawą zamkniętą.

W październiku 2009 roku Republika Czeska wystąpiła z żądaniem, aby została objęta protokołem nr 30 traktatu lizbońskiego, co zostało zaakceptowane na szczycie UE i umożliwiło byłemu prezydentowi Václavovi Klausovi podpisanie aktu ratyfikacyjnego Traktatu z Lizbony. Oficjalnym powodem, dla którego prezydent Klaus nalegał na włączenie Republiki Czeskiej w zakres obowiązywania przedmiotowego protokołu była obawa dotycząca wpływu postanowień Karty na prawomocność dekretów Benesza. Wskazane akty prawne dotyczyły deportacji i konfiskaty majątku rdzennych Niemców z terytorium Czechosłowacji po II wojnie światowej. Należy wspomnieć, że Trybunał Konstytucyjny $\mathrm{Czech}^{6}$ oddalił w 2008 r. petycję, uznając, że Traktat z Lizbony jest w pełni zgodny z prawem konstytucyjnym Czech oraz że Parlament czeski ratyfikował Traktat z Lizbony dokładnie w takiej wersji, w jakiej został on podpisany, bez jakichkolwiek zastrzeżeń

2 Art. 18 TFUE — Traktat o fukcjonowaniu Unii Europejskiej, Dz.U. C 326, 26/10/2012.

3 Dz.U. UE 2012 C 326, s. 2.

4 Traktat z Lizbony zmieniający Traktat o Unii Europejskiej i traktat ustanawiający Wspólnotę Europejską, sporządzony w Lizbonie dnia 13 grudnia 2007 r. (Dz.U. z 2009 r. Nr 203, poz. 1569).

5 Traktat o funkcjonowaniu Unii Europejskiej. Komentarz, t. 1, red. D. Miąsik, N. Półtorak, A. Wróbel, Warszawa 2012, s. 218.

6 Pl.ÚS 19/08 z dnia 26 listopada 2008 r., 446/2008 Sb. 
odnoszących się do pełnego poszanowania Karty przez Republikę Czeską ${ }^{7}$. W odróżnieniu od protokołu polskiego oraz brytyjskiego protokół czeski nie został przyjęty w sposób klasyczny przez dołączenie protokołu do Traktatu z Lizbony, ale w ramach konkluzji Rady Europejskiej w dniach 29 i 30 października 2009 r. i miał zostać zastosowany ex post. Oznacza to, że czeski protokół nie uznajemy za przypadek opt out (polski wyjątek również nim nie jest) ${ }^{8}$ ani za umownie ustalony protokół, ale raczej za deklarację polityczną. Protokół 30, którego celem nie jest ograniczenie stosowania Karty ${ }^{9}$, ale tylko sprecyzowanie stosowania w stosunku do działań administracyjnych i przepisów prawnych Zjednoczonego Królestwa i Polski oraz możliwości w tych państwach rozpoznawania na podstawie Karty spraw na drodze sądowej ${ }^{10}$, zyskał moc obowiązującą od wejścia w życie Trakta$\mathrm{tu}^{11}$. Jednak czeski protokół miał zostać dodany dopiero do następnej zmiany traktatu UE ${ }^{12}$. W okresie od Traktatu Lizbońskiego do traktatu akcesyjnego Chorwacji protokół czeski zatem nie obowiązywał przed sądami czeskimi. W tym czasie nie pojawiła się zresztą żadna sprawa dotycząca stosowania Karty w związku z dekretami Benesza.

Protokół czeski miał zostać dołączony do traktatu akcesyjnego Chorwacji do UE. Z opinii Komisji Europejskiej wynikało jednak, że dołączenie protokołu oraz akcesja Chorwacji podlegają różnej procedurze prawnej i nie mogą zostać połączone. Jednocześnie czeski Senat sprzeciwił się protokołowi ze względu na obawę TK, że doprowadzi on do zmniejszenia ochrony prawnej obywateli RCZ, co jest niezgodne z konstytucją i powoduje niemożność ratyfikacji takiego traktatu ${ }^{13}$. Ponadto żadna z partii politycznych nie podtrzymywała twierdzenia, że dekrety Benesza nadal wywołują wątpliwości prawne w odniesieniu do praw majątkowych w Sudetach. Eksperci oraz rząd RCZ podkreślali, że Karta nie rozszerza zakresu

7 Sprawozdanie Parlamentu Europejskiego z dnia 16 maja 2013 w sprawie projektu protokołu w sprawie stosowania Karty praw podstawowych Unii Europejskiej do Republiki Czeskiej (art. 48 ust. 3 Traktatu o Unii Europejskiej, 00091/2011 — C7-0385/2011 - 2011/0817(NLE)).

8 A. Błachnio-Parzych et al., Karta Praw Podstawowych Unii Europejskiej. Komentarz, Warszawa 2012, s. 2.

9 Rząd Polski, Trybunał Sprawiedliwości UE oraz większość doktryny wyrażają pogląd, że protokół nie ogranicza stosowana Karty do Zjednoczonego Królestwa oraz Polski. Potwierdził to Trybunał Sprawiedliwości UE w wyroku w sprawach połączonych C-411/10 oraz C-493/10N.S., oraz w wyroku w sprawie C-489/10 Bonda.

10 Motyw 9 preambuły do protokołu nr 30.

11 Odpowiedź podsekretarza stanu w Ministerstwie Spraw Zagranicznych z upoważnienia prezesa Rady Ministrów na interpelację nr 22476 w sprawie odstąpienia Polski od protokołu nr 30 traktatu lizbońskiego z dnia 13 grudnia 2007 r., http://www.sejm.gov.pl/Sejm7.nsf/InterpelacjaTresc. xsp?key=440B1ED5 (dostęp: 15.10.2015).

12 Następną zmianą traktatu UE była akcesja Chorwacji do UE.

13 Trybunał Konstytucyjny RCZ — Pl.ÚS 36/01 z dnia 25 czerwca 2002, 403/2002 Sb. N 80/26 SbNU 317, Odména a náhrada výdajů správce konkursní podstaty. Ústavni pořádek. Zákaz snižení dosažené procedurální úrovně ochrany základních práv. 
kompetencji Unii oraz powoływali się na treść art. 345 TFUE, który stanowi, że traktaty nie przesądzają w niczym zasad prawa własności w państwach członkowskich. Deklaracja polityczna marcowego szczytu UE w 2009 r. potwierdziła również wyłączenie wstecznego działania Karty, zwłaszcza na lata $1940-46^{14}$.

Parlament Europejski w maju 2013 roku zalecił państwom członkowskim, żeby danego protokołu nie brały pod uwagę i nie rozpoczynały procesu jego ratyfikacji, dopóki proces ten nie zostanie zakończony w $\mathrm{RCZ}^{15}$. W lutym 2014 roku rząd RCZ pod przewodnictwem premiera Miroslava Sobotki nakazał Ministerstwu Spraw Zagranicznych, aby zakończyło negocjacje czeskiego protokołu, opierając się na uznaniu, że „Karta ma być w pełni stosowana wobec obywateli RCZ”. Uznał również powody przywoływane przy przyjmowaniu protokołu za bezpodstawne. Dalszy jego los zależy więc od stanowiska UE oraz rządu RCZ, jednak najprawdopodobniej RCZ zrezygnuje z protokołu, zanim formalnie zacznie on obowiązywać.

Karta Praw podstawowych regulująca kwestie dyskryminacji w tytule III (Równość) w pełni obowiązuje na terytorium Republiki Czeskiej. Wynika z niej prawo każdej osoby, która uważa, że prawa i wolności znajdujące się w Karcie są łamane, do skutecznej ochrony prawnej przed sądem ${ }^{16}$. Sądownictwo czeskie uzyskało również na podstawie art. 267 TFUE możliwość zwracania się z pytaniem prejudycjalnym ${ }^{17}$ do Trybunału Sprawiedliwości o interpretację prawa unijnego ${ }^{18}$.

\section{Prawo pierwotne Unii Europejskiej $\mathrm{w}$ walce $\mathrm{z}$ dyskryminacją}

Głównym źródłem prawa antydyskryminacyjnego w prawie pierwotnym UE są traktaty założycielskie. Zakaz dyskryminacji ze względu na płeć w odniesieniu do zatrudnienia pojawił się już w momencie utworzenia Europejskiej Wspólnoty Gospodarczej w 1957 roku $^{19}$. Miał on uniemożliwić powstanie nierównego

${ }^{14}$ M. Forejtová, Výjimky z Listiny základních práv EU pro ČR?, http://www.pravniprostor. cz/clanky/mezinarodni-a-evropske-pravo/vyjimky-z-listiny-zakladnich-prav-eu-pro-cr (dostęp: 15.10.2015).

15 Sprawozdanie Parlamentu Europejskiego z dnia 16 maja 2013, s. 2.

16 Artykuł 47 Karty Praw Podstawowych.

17 Ł. Bojarski et al., Karta Praw Podstawowych Unii Europejskiej jako żywy instrument, Podręcznik dla prawników, Warszawa 2014, s. 17.

18 Agencja Praw Podstawowych, Rada Europy, Podręcznik europejskiego prawa o niedyskryminacji, Urząd Publikacji Unii Europejskiej, 2011, s. 16.

19 Najważniejszym celem Wspólnot Europejkich było zainicjowanie integracji gospodarczej państw. Równość pojmowana jako podstawowe prawo człowieka nie była wtedy jednak pierwszorzędna. Wspólnota liczyła w tym zakresie na regulacje Rady Europy. Por. M.A. Nowicki, Opinia dla Komisji Spraw Zagranicznych i Integracji Europejskiej Senatu Rzeczypospolitej Polskiej na temat Karty Praw Podstawowych UE http://sbc.org.pl/Content/20174/poltorak.pdf (dostęp: 10.10.2015).

Prawo 320, 2016

(C) for this edition by CNS 
statusu państw przez oferowanie kobietom niższych wynagrodzeń lub gorszych warunków pracy. W późniejszych latach zakaz dyskryminacji rozciągnął się również na sprawy emerytalne, zabezpieczenia społecznego i inne, jednak ograniczał się wyłącznie do zakazu dyskryminacji ze względu na płeć ${ }^{20}$. Zmienił to Traktat Amsterdamski z $1999 \mathrm{r}^{21}$, który za jeden z podstawowych celów uznał likwidację dyskryminacji oraz propagowanie równości kobiet i mężczyzn. Traktat Amsterdamski wprowadził do części I Traktatu ustanawiającego Wspólnotę Europejską, zatytułowanej Zasady artykuł 13, który stwarzał możliwości działań wspólnotowych nakierowanych na zwalczanie dyskryminacji. Zgodnie z artykułem 13 TWE Wspólnota mogła podjąć środki niezbędne do zwalczania wszelkiej dyskryminacji ze względu na płeć, rasę, pochodzenie etniczne, religię, przekonania, niepełnosprawność, wiek lub orientację seksualną ${ }^{22}$. Celem tego artykułu było zapobieganie dyskryminacji na podstawie różnych kryteriów, nie tylko ze względu na płeć. Chociaż katalog podstaw dyskryminacji z art. 13 TWE wydawał się katalogiem zamkniętym, został on jednak rozszerzony orzecznictwem TSUE ${ }^{23}$. Traktat Amsterdamski w dawnym art. 141 TWE wprowadził również możliwość stosowania działań pozytywnych w celu zapewnienia stosowania zasady równości szans w zatrudnieniu ${ }^{24}$. Obecnie kwestie antydyskryminacyjne zostały uregulowane w Traktacie o funkcjonowaniu UE. Podstawowe są artykuły 18 oraz 19 TFUE. Pierwszy z nich określa zakaz dyskryminacji ze względu na przynależność państwową ${ }^{25}$. Na podstawie art. 19 TFUE $^{26}$ Rada, działając na wniosek Komisji, ma możliwość podjęcia działań w celu zwalczania wszelkiej dyskryminacji.

Wspieranie równości szans w całej Unii zgodne jest z art. 2 i 3 Traktatu o UE. Jednak w prawie pierwotnym równość kobiet i mężczyzn regulowana jest obecnie

${ }^{20}$ Podręcznik europejskiego prawa..., s. 14.

21 Traktat z Amsterdamu zmieniający Traktat o Unii Europejskiej, traktaty ustanawiające Wspólnoty Europejskie i niektóre związane z nimi akty (tzw. Traktat Amsterdamski) — podpisany 2 października 1997 r. (wszedł w życie 1 maja 1999 r.) — Dz.U. z 2004 r., Nr 90, poz. 864/31.

22 T. Wawrowski, Polityka równych szans. Instytucjonalne mechanizmy zwiększania partycypacji kobiet $w$ strukturach politycznych na przykładzie państw Unii Europejskiej, Toruń 2007, s. 231 oraz http://rownetraktowanie.gov.pl/dyskryminacja-ze-wzgledu-na-plec http://sbc.org.pl/ Content/20174/poltorak.pdf (dostęp: 10.10.2015).

23 ICOS Český Krumlov ve spolupráci s Českým helsinským výborem, Soudní praxe v oblasti diskriminace na trhu práce, Analýza judikatury Evropské unie a českých soudů, Český Krumlov 2008, s. 6.

24 Uprawnienie to „nie stanowi przeszkody dla Państwa Członkowskiego w utrzymaniu lub przyjmowaniu środków przewidujących specyficzne korzyści, zmierzające do ułatwienia wykonywania działalności zawodowej przez osoby płci niedostatecznie reprezentowanej bądź zapobiegania niekorzystnym sytuacjom w karierze zawodowej i ich kompensowania”. Art. 141 Traktatu Amsterdamskiego.

25 Nadaje Radzie oraz Parlamentowi Europejskiemu uprawnienie do przyjmowania wszelkich przepisów dla ochrony przed taką dyskryminacją.

26 A. Wróbel, [w:] Traktat o funkcjonowaniu Unii..., s. 253. 
zwłaszcza w art. 19 TFUE $^{27}$, art. 153 TFUE (równość na rynku pracy i traktowaniu w pracy) oraz art. 157 TFUE (równość wynagrodzeń) ${ }^{28}$.

Podsumuwując, w systemie prawa Unii Europejskiej prawo pierwotne ma najwyższą rangę, gdyż zawiera przepisy regulujące podstawowe zasady funkcjonowania Unii Europejskiej. Jedną z tych zasad jest zakaz dyskryminacji. Akty prawa pierwotnego cechuje bezpośrednie obowiązywanie. Oznacza to, że przedstawione normy zakazujące dyskryminację od dnia wejścia w życie są częścią porządku prawnego, który obowiązuje w państwach członkowskich ${ }^{29}$, bez wymagania wdrożenia do czeskiego porządku prawnego. Podmioty prawa (np. osoby fizyczne lub prawne) mogą bezpośrednio powoływać się na te normy w postępowaniu przed czeskimi sądami i czeskimi organami administracyjnymi, co jest wynikiem bezpośredniego stosowania tych norm ${ }^{30}$.

\section{Zasada równości w prawie wtórnym Unii Europejskiej}

UE zwalcza dyskryminację zwłaszcza poprzez przyjmowanie dyrektyw ${ }^{31}$. Dyrektywy zaliczane są do źródła prawa wtórnego, które znajduje swoje umocowanie w traktatach UE. Wiążą one każde państwo członkowskie, do którego są kierowane. W odniesieniu do rezultatu, który ma być osiągnięty, pozostawiają jednak organom krajowym swobodę wyboru formy i środków ${ }^{32}$. Wdrożenie dyrektyw do porządku prawnego państw członkowskich w znaczeniu ogólnym według C. Mika oznacza skuteczne wprowadzenie w życie aktu prawnego ${ }^{33}$.

27 Określa środki w celu zwalczania dyskryminacji, między innymi na podstawie płci w zatrudnieniu, ale nie tylko.

28 Przepisy prawa krajowego nie mogą przeważać nad prawem traktatowym, będącym nadrzędnym i niezależnym źródłem prawa. Podstawą zasady nadrzędności prawa wspólnotowego nad prawem państw członkowskich stało się orzeczenie 6/64 ETS z 1964 roku Costa/ENEL.

29 W. Kałwak, Przewodnik po prawie Unii Europejskiej, Warszawa 2010, s. 15.

30 Akty prawa pierwotnego charakteryzuje bezpośrednie obowiązywanie, bezpośrednie stosowanie oraz bezpośredni skutek.

31 Kolejnym sposobem są komunikaty np. komunikat Komisji z 2008 r. ustalający wszechstronne podejście do wzmocnienia działań mających na celu ograniczenie dyskryminacji i promowanie równych szans oraz decyzję Komisji powołującą rządową grupę ekspertów ds. niedyskryminacji, http://ec.europa.eu/justice/discrimination/index_pl.htm (dostęp: 11.10.2015).

32 Artykuł 288 TFUE.

33 Procedura wdrażania podlega przede wszystkim zasadom efektywności i asymilacji. Por. C. Mik, Europejskie prawo wspólnotowe. Zagadnienia teorii i praktyki, t. 1, Warszawa 2000, s. 35 n.; Według W. Voermans i P. Eijlandera wdrażanie to: „proces, w którym prawo krajowe jest modyfikowane zgodnie z prawem Unii", cyt. za: E. Galewska, Implementacja dyrektyw telekomunikacyjnych, Kraków 2007, s. 56. 
Pierwsze dyrektywy antydyskryminacyjne zostały przyjęte w latach 70 . XX wieku, kiedy z powodu rosnącego bezrobocia i recesji gospodarczej odrzucono ideę samodzielnego rozwoju gospodarczego wspólnot europejskich. Zauważono konieczność regulacji niektórych zagadnień społecznych. Pierwsza kwestia uregulowana w dyrektywie Rady 75/117/EWG ${ }^{34}$, znajdująca swoją podstawę w prawie pierwotnym, wprowadza w życie stosowanie zasady równości wynagrodzeń dla kobiet i mężczyzn ${ }^{35}$. Bardziej ogólna dyrektywa w sprawie wprowadzenia w życie zasady równego traktowania kobiet i mężczyzn w zakresie dostępu do zatrudnienia, kształcenia i awansu zawodowego oraz warunków pracy ${ }^{36}$ została przyjęta 9 lutego $1976 \mathrm{r}^{37}$

Efektem przyjęcia w 1999 r. Traktatu z Amsterdamu UE była możliwość zwalczania dyskryminacji nie tylko ze względu na płeć, ale również ze względu na nowe przyczyny dyskryminacji. Na podstawie dawnego art. 13 TWE (obecnie art. 19 Traktatu o funkcjonowaniu EU) zostały przez państwa członkowskie jednomyślnie przyjęte dyrektywy w sprawie równego traktowania w zatrudnieniu i pracy $\left(2000 / 78 / \mathrm{WE}^{38}\right)$ oraz dyrektywy o równości rasowej $(2000 / 43 / \mathrm{WE})^{39}$.

Wzrost migracji osób w państwach członkowskich UE spowodował rozrost zjawiska ksenofobii i rasizmu, co przyczyniło się do tego, że Unia Europejska poświęciła kwestii dyskryminacji rasowej szczególną uwagę. Dyskryminacja ze względu na pochodzenie etniczne lub rasowe może uniemożliwić osiągnięcie jednego z podstawowych celów UE, którym jest utworzenie przestrzeni bezpieczeństwa, wolności i sprawiedliwości. W celu ochrony przed taką dyskryminacją dyrektywa 2000/43/WE jako pierwsza wykracza poza działalność zarobkową i obejmuje dziedziny takie jak opieka społeczna, w której skład wchodzi opieka zdrowotna oraz bezpieczeństwo socjalne, edukacja, dostęp do/dostarczanie dóbr i usług, ułatwienia społeczne ${ }^{40}$.

Dyrektywa rady 2004/113/WE ${ }^{41} \mathrm{z}$ dnia 13 grudnia 2004 r. skonkretyzowała zasadę równego traktowania mężczyzn i kobiet w zakresie dostępu do towarów i usług oraz dostarczania towarów i usług. W 2006 r. kwestie równego traktowania kobiet i mężczyzn w dziedzinie zatrudnienia i pracy zostały skumulowane i odno-

34 Dyrektywa 75/117/EWG w sprawie zbliżenia ustawodawstw Państw Członkowskich dotyczących stosowania zasady równości wynagrodzeń dla kobiet i mężczyzn, Dz.U. L 45, 19/02/1975.

35 Chroniła również przed zwolnieniem pracowników domagających się swoich praw do równego wynagradzania. Por. K. Kędziora, K. Śmiszek, Dyskryminacja i mobbing w zatrudnieniu, Warszawa 2003, s. 20.

36 Dyrektywa Rady 76/207/EWG.

37 Soudni praxe..., s. 9.

38 Dyrektywa Rady 2000/78/WE z dnia 27 listopada 2000 r. ustanawiająca ogólne warunki ramowe równego traktowania w zakresie zatrudnienia i pracy, Dz.U. WE L 303, 2/12/2000.

39 Dyrektywa Rady 2000/43/WE z dnia 29 czerwca 2000 r. wprowadzającą w życie zasadę równego traktowania osób bez względu na pochodzenie rasowe lub etniczne, Dz.U. WE L 180, 19/07/2000.

40 Preambuła dyrektywy Rady 2000/43/WE.

41 Dz.U. UE L 373, 21/12/2004, str. 37. 
wione ${ }^{42} \mathrm{w}$ dyrektywie $2006 / 54 / \mathrm{WE}^{43}$. Dyrektywa ta połączyła i usprawniła przepisy wynikające z poprzednich dyrektyw, dołączyła również nowe elementy ${ }^{44}$, wynikające z orzecznictwa Trybunału Sprawiedliwości UE ${ }^{45}$.

Rok 2007 został ustanowiony „Europejskim Rokiem na rzecz Równych Szans dla Wszystkich”46 (dalej „Europejski Rok”). Spowodowało to uznanie kwestii wszelkich form dyskryminacji oraz różnorodności za zagadnienia pierwszorzędne. Do jego głównych celów zaliczono ułatwienie dostępu do informacji o prawach (również prawodawstwa europejskiego) osób narażonych na dyskryminację, zachęcanie do lepszych stosunków w ramach społeczeństwa, poparcie akceptacji różnorodności oraz równości ${ }^{47}$. Poziom sukcesu wydarzenia został opisany w sprawozdaniu z działalności UE przeciwko dyskryminacji w latach 2007-2008; uznano, że przyczyniono się do powiększenia wiedzy społeczeństwa w kwestii wyrównywania szans, zjednoczono osoby oraz organizacje wokół wspólnego celu ${ }^{48}$.

Unijny dorobek prawa antydyskryminacyjnego określa nie tylko ścisły katalog obowiązków i praw we wszystkich państwach członkowskich UE, ale również ustala procedury, które mają pomóc ofiarom dyskryminacji. Ustala cztery podstawowe prawa o charakterze proceduralnym wszystkich obywateli UE: prawo ochrony przed dyskryminacją (bezpośrednią i pośrednią), pomoc od organów wewnętrznych państwa zajmujących się kwestiami równości, równego traktowania w zatrudnieniu oraz możliwość złożenia skargi w postępowaniu administracyjnym lub sądowym ${ }^{49}$.

42 Celem połączenia przepisów w jednej dyrektywie było polepszenie i aktualizacja prawa wspólnotowego w kwestii równego traktowania kobiet i mężczyzn. Por. L. Mitrus, Rozwój prawa wspólnotowego $w$ dziedzinie równego traktowania kobiet $i$ mężczyzn $w$ zatrudnieniu, Warszawa 2007, s. 1.

43 Dyrektywa 2006/54/WE Parlamentu Europejskiego i Rady z dnia 5 lipca 2006 r. w sprawie wprowadzenia $\mathrm{w}$ życie zasady równości szans oraz równego traktowania kobiet i mężczyzn w dziedzinie zatrudnienia i pracy, Dz.U. UE L 204, 26/07/2006, s. 23.

44 Do nowych elementów należą: definicja wynagrodzenia, bezpośrednie stosowanie do dyskryminacji ze względu na zmianę płci oraz wprowadzenie zasady równego traktowania emerytalnego dla specjalnych grup pracowników.

45 A. Pomaska, Opinia w sprawie sprawozdania Komisji dla Parlamentu Europejskiego $i$ Rady z dnia 5 lipca $2006 r$. w sprawie wprowadzenia $w$ życie zasady równości szans oraz równego traktowania kobiet i mężczyzn w dziedzinie zatrudnienia i pracy (wersja przeredagowana), Warszawa 2014 , s. 1.

46 Decyzja nr 771/2006/WE Parlamentu Europejskiego i Rady z dnia 17 maja 2006 r. ustanawiająca Europejski Rok na rzecz Równych Szans dla Wszystkich (2007) — w Kierunku Sprawiedliwego Społeczeństwa, Dz.U. L 1146, 31/05/2006P. 0001-0007.

47 Stanowisko Parlamentu Europejskiego przyjęte w pierwszym czytaniu w dniu 13 grudnia 2005 r. w celu przyjęcia decyzji nr 1600/2002/WE(4)/2006/WE Parlamentu Europejskiego i Rady w sprawie Europejskiego Roku na rzecz Równych Szans dla Wszystkich (2007) — w Kierunku Sprawiedliwego Społeczeństwa.

48 Komisja Europejska, dyrekcja Generalna ds. Zatrudnienia, Spraw Społecznych i Równości Szans, Działania Unii Europejskiej przeciwko dyskryminacji, Sprawozdanie z działalności w latach 2007 i 2008, Luksemburg 2009, s. 5.

49 Komisja Europejska, Równość: przepisy UE dotyczace przeciwdziałania dyskryminacji obowiazują teraz we wszystkich 28 państwach UE, (komunikat prasowy), Bruksela 2014.

Prawo 320, 2016

(C) for this edition by CNS 


\section{Wybrane orzecznictwo Trybunału Sprawiedliwości UE w sprawie dyskryminacji}

Dyrektywy, jako sposób harmonizacji praw państw członkowskich, zobowiązują państwa członkowskie do wdrażania rozwiązań prawnych, a w ten sposób określają pewien minimalny stopień ochrony przed dyskryminacją ${ }^{50}$. Pewne warunki określa jednak również judykatura Trybunału Sprawiedliwości UE. Pierwszym orzeczeniem wartym przedstawienia jest wyrok Trybunału z dnia 10 kwietnia 1984 r. w sprawie Von Colson 14/83 51 , określający równe traktowanie mężczyzn i kobiet w dostępie do zatrudnienia. W orzeczeniu tym Trybunał uznał, że: ,skuteczna transpozycja dyrektywy wymaga, żeby sankcje były tak skonstruowane, aby z jednej strony zapewnić dyskryminowanemu kandydatowi należyte naprawienie szkody, a z drugiej być skutecznym środkiem nacisku na pracodawcę, skłaniającym go do respektowania zasady równego traktowania. Uregulowania krajowe przewidujące jedynie prawo do odszkodowania za poniesioną szkodę nie są wystarczające dla zapewnienia przestrzegania tej zasady"52. Wybrane przez państwa środki ochrony powinny być wystarczająco pewne (skuteczne), wiarygodne, dostępne dla wszystkich dyskryminowanych osób oraz nadające się rzeczywiście do zastosowania ${ }^{53}$. O wysokości odszkodowania osób dyskryminowanych Trybunał orzekł w dniu 22 kwietnia 1997 r. w sprawie Nils Draehmpaehl v Urania Immobilienservice $\mathrm{OHG}^{54}$. Trybunał uznał, że jeżeli państwo członkowskie zdecyduje się nałożyć sankcje odszkodowawcze za naruszenie zakazu dyskryminacji, to sankcje takie powinny gwarantować realną i efektywną ochronę sądową, mieć rzeczywisty efekt odstraszający oraz odpowiadać rzeczywiście poniesionej szkodzie pokrzywdzonego. W celu zapewnienia wystarczająco skutecznej sankcji Trybunał ustalił, że jest niezgodne z dyrektywą ${ }^{55}$ ustalanie górnej

50 B. Kurcz, Harmonisation by means of Directives — never-ending story, ,Europen Bussiness Law Rewiev” 2001, nr 11-12, s. 288.

51 Sprawa 14/83 mająca za przedmiot skierowany do Trybunału na podstawie art. 177 traktatu EWG przez Arbeitsgericht w Hamm wniosek o wydanie, w ramach zawisłego przed tym sądem sporu między Sabine von Colson i Elisabeth Kamann a Land Nordrhein-Westfalen, orzeczenia w trybie prejudycjalnym w sprawie wykładni dyrektywy Rady nr 76/207 z dnia 9 lutego 1976 r. w sprawie wprowadzenia w życie zasady równego traktowania kobiet i mężczyzn w zakresie dostępu do zatrudnienia, kształcenia i awansu zawodowego oraz warunków pracy (Dz.U. L 39, str. 40).

$52 \mathrm{http}: /$ curia.europa.eu/arrets/TRA-DOC-PL-ARRET-C-0014-1983-200407000-05_02.html (dostęp: 12.10.2015).

53 W katalogu środków ochrony wybranych przez państwa nie musi być jednak obowiązku zawarcia umowy o pracę z osobą dyskryminowaną.

54 ECLI:EU:C:1997:208.

55 Mowa o dyrektywie Rady 76/207/EWG z dnia 9 lutego 1976 r. w sprawie wprowadzenia w życie zasady równego traktowania kobiet i mężczyzn w zakresie dostępu do zatrudnienia, kształcenia i awansu zawodowego oraz warunków pracy.

Prawo 320, 2016

(C) for this edition by CNS 
granicy odszkodowania (np. trzymiesięczne wynagrodzenie) w państwie członkowskim w sytuacji, kiedy stwierdzono, iż dyskryminowany uzyskałby wolne stanowisko, jeżeli nie byłby dyskryminowany w procedurze wyboru ${ }^{56}$. Również granica sześciomiesięcznego wynagrodzenia dla łącznej wysokości odszkodowania wobec wszystkich kandydatów dyskryminowanych ze względu na płeć przez danego pracodawcę w trakcie rekrutacji może doprowadzić, według Trybunału, do raczej symbolicznej kompensaty, która nie może być uważana za skuteczny środek zgodny z przepisami unijnymi ${ }^{57}$. W sprawie Vejdeland i innych przeciwko Szwecji z dnia 9 lutego $2012^{58}$ ETS określił również standard ochrony przed dyskryminacją ze względu na orientację seksualną i nadał jej nowy wymiar, porównując ją do rasizmu i ksenofobii. Ze wględów praktycznych przedstawione zostały tylko przykładowe orzecznictwa Trybunału w sprawach dyskryminacyjnych, jednak bogate orzecznictwo Trybunału ma znaczący wpływ na stosowanie prawa antydyskryminacyjnego w państwach członkowskich ${ }^{59}$.

\section{Procedura wdrożenia unijnej zasady niedyskryminacji na przykładzie czeskiego prawa pracy}

Republika Czeska jako wolne i demokratyczne państwo szanujące prawa człowieka i zasady społeczeństwa obywatelskiego, które jest częścią rodziny europejskich i światowych demokracji ${ }^{60}$, ustala w swoim porządku prawnym zakaz dyskryminacji. Podstawę zasady niedyskryminacji w czeskim porządku prawnym znajdziemy już w tzw. porządku konstytucyjnym Republiki Czeskiej. Konstytucja RCZ w szerszym znaczeniu (polylegální ústava) obejmuje nie tylko Konstytucję $\mathrm{RCZ}^{61} \mathrm{w}$ wąskim znaczeniu (czyli jeden akt prawny), ale również Kartę Podsta-

56 Inaczej wygląda sytuacja, jeżeli pracodawca udowodni, że ze względu na wysokie kwalifikacje wybranego kandydata poszkodowany nie uzyskałby stanowiska, nawet jeżeli nie byłoby żadnej dyskryminacji w procedurze wyboru. W takiej sytuacji ustalenie granicy odszkodowania (np. trzymiesięcznego wynagrodzenia) przez państwo członkowskie nie jest niezgodne z prawem UE.

57 H. Zemanová Šimanová, Soudni prostředky ochrany před diskriminaci v pracovněprávnich vztazich, Brno 2010, s. 2.

58 Sprawa ze skargi nr 1813/07.

59 Więcej na temat orzecznictwa Trybunału w sprawach dyskryminacyjnych można znaleźć np. w: K. Kędziora, K. Śmiszek, Wybrane orzecznictwo sądów krajowych i międzynarodowych w sprawach o dyskryminacje, Warszawa 2013.

60 Preambuła Konstytucji RCZ.

61 Ústavá České republiky, ústavní zákon č. 1/1993. Sb. uchwalona przez Czeską Radę Narodową dnia 16 grudnia 1992 r. składa się z Preambuły i 113 artykułów podzielonych na 8 części, a weszła w życie na podstawie art. 113, dnia 1 stycznia $1993 \mathrm{r}$. 
wowych Praw i Wolności (Karta RCZ) ${ }^{62}$ i inne dokumenty. Potwierdza to art. 3 Konstytucji RCZ z 1993 r., który stanowi, że: „Częścią porządku konstytucyjnego RCZ jest Karta Podstawowych Praw i Wolności”. Konstytucja oraz Karta RCZ mają dominującą pozycję ${ }^{63} \mathrm{w}$ hierarchii porządku prawnego $\mathrm{RCZ}^{64}$. Konstytucja RCZ z 1993 r. pośrednio tylko ustala zasadę niedyskryminacji ${ }^{65}$, jednak Karta RCZ $\mathrm{w}$ art. 3 określa już bezpośrednią gwarancję tego, że podstawowe prawa i wolności należą do wszystkich bez względu na płeć, rasę, kolor skóry, język, wiarę i religię, przekonania polityczne i inne, pochodzenie narodowe lub społeczne, przynależność do mniejszości narodowej lub etnicznej, majątek, urodzenie bądź ze względu na jakiekolwiek inne przyczyny.

Ogólny zakaz dyskryminacji wynikający z porządku konstytucyjnego RCZ rozwijają kolejne akty prawne rangi ustawowej zawierające skonkretyzowane przepisy prawne związane z zasadą niedyskryminacji. Należą do nich np. ustawa o zatrudnieniu ${ }^{66}$, kodeks pracy ${ }^{67}$, kodeks cywilny ${ }^{68} \mathrm{i}$ inne.

Podstawowym czeskim aktem prawnym z zakresu prawa pracy jest kodeks pracy. Zobowiązania RCZ związane $\mathrm{z}$ wdrożeniem ${ }^{69}$ unijnego prawa o niedyskryminacji $\mathrm{w}$ dziedzinie prawa pracy zostało najpierw przeprowadzone za pomocą tzw. euronowelizacji kodeksu pracy ${ }^{70}$. Pierwsza nowelizacja ${ }^{71}$, uchwalona w 2000 r., wprowadziła do kodeksu większość ustaleń dyrektyw unijnych. Ustanowiła $\mathrm{w}$ kodeksie zasadę równego traktowania oraz zakaz dyskryminacji na podstawie katalogu możliwych podstaw dyskryminacji. Druga euronowelizacja ${ }^{72}$ wprowadziła do kodeksu z zakresu prawa do niedyskryminacji definicje pojęć, takich jak molestowanie, molestowanie seksualne, dyskryminacja pośrednia oraz bezpośrednia ${ }^{73}$. Definicje te zgodne były z definicjami ustalonymi w dyrektywach

${ }^{62}$ Listina základních práv a svobod, przyjęta jeszcze w czasie istnienia Czechosłowacji 9 stycznia 1991 r., na mocy ustawy č. 23/1991 Sb., wprowadzona jako ustawa konstytucyjna Czeskiej i Słowackiej Republiki Federacyjnej. Republika Czeska przyjęła ją č.2/1993Sb. dnia 16 grudnia 1992 r., ze zmianami č. 162/1998Sb.

63 V. Pavlíček et al., Ústavni právo a státověda, t. 2, Ústavní právo České republiky, Praha 2011, s. 118.

64 Więcej informacji na s. 6 i w kolejnej części pracy autorki. Por. E. Matlochová, Uprawnienia polskiej mniejszości narodowej w Republice Czeskiej, „Folia Iuridica Universitatis Wratislaviensis” vol. 2, 2013, $\mathrm{nr} 2$.

65 Art. 4 gwarantuje „poddanie praw i wolności człowieka ochronie władzy sądowniczej”.

66 Zákon o zaměstnanosti z dnia 13 maja 2004 r. z późn. zm., č. 435/2004 Sb.

67 Zákoník práce z dnia 21 kwietnia 2006 r., obowiązuje od 1 stycznia 2007 r., č. 262/2006 Sb.

68 Občanský zakoník z dnia 3 lutego 2012 r., č. 89/2012Sb.

69 Pojawiają się sytuacje, kiedy zamiennie stosuje się pojęcia „wdrożenie” oraz „transpozycja” (aktów prawnych wydawanych przez organy Unii Europejskiej, orzeczeń TSUE). Por. B. Kurcz, Dyrektywy Wspólnoty Europejskiej i ich implementacja do prawa krajowego, Kraków 2004, s. 45.

70 Mowa o starym kodeksie pracy, zakoník prace č. 65/1965.

71 Ustalona na podstawie ustawy - Zákon č. 155/2000 Sb., obowiązująca z pewnymi wyjątkami od 1 stycznia $2001 \mathrm{r}$.

72 Ustalona na podstawie ustawy — zákon č. 46/2004 Sb. obowiązująca od 1 marca 2004 r.

73 E. Dandová, Zákoník práce a EU: V otázkách a odpovédích, Praha 2004, s. 8 n. 
unijnych. Kodeks pracy obowiązujący do 31 grudnia 2006 r. był rezultatem harmonizacji czeskiego porządku prawnego z prawem UE. Te dwie euronowele w połączeniu $\mathrm{z}$ kolejnymi uzupełniały również inne akty prawa pracy w taki sposób, że w zakresie prawa pracy przepisy antydyskryminacyjne stosunkowo skutecznie spełniały wymogi UE. Stan ten zmienił się jednak kategorycznie, kiedy zaczął obowiązywać nowy kodeks pracy (KP). Ten już w swych normach prawnych regulujących zasadę równego traktowania oraz zakazu dyskryminacji, liczył się $\mathrm{z}$ istnieniem ustawy antydyskryminacyjnej ${ }^{74}$, która zaczęła obowiązywać dopiero 1 stycznia $2009 \mathrm{r}^{75}$. Szczegółowe przepisy antydyskryminacyjne kodeksu pracy z 1965 r. zostały zastąpione przepisami odsyłającymi do ustawy antydyskryminacyjnej ${ }^{76}$. W pewnym zakresie doszło jednak do pogorszenia sytuacji prawnej, ponieważ obecna ustawa antydyskryminacyjna zakazuje dyskryminacji tylko ze względu na rasę, pochodzenie etniczne, narodowość, płeć, orientację seksualną, wiek, niepełnosprawność, religię, wiarę lub wyznanie, ubezpieczenie zdrowot$\mathrm{ne}^{77}$. Kodeks pracy z 1965 r. zakazywał dyskryminacji w zatrudnieniu również na innych podstawach np. stanu cywilnego oraz rodzinnego, obywatelstwa, przynależność do partii politycznych, obowiązków rodzinnych ${ }^{78}$.

Pierwszy projekt ustawy antydyskryminacyjnej pojawił się już w 2004 r., do Sejmu jednak został przekazany dopiero w styczniu 2005 r., gdzie został rozpatrzony i uchwalony pod numerem 866 . W Senacie projekt rozpatrzono pod numerem 201, został jednak przez niego odrzucony i zwrócony do głosowania Sejmu. Sejmowi nie udało się przegłosować uchwały Senatu o odrzuceniu ustawy, co oznaczało jej upadek w dniu 23 maja $2006 \mathrm{r}$. Ze względu na niezadowalającą sytuację w regulacji zakazu dyskryminacji, która spowodowała uruchomienie czterech postępowań ze skargą z powodu niewykonania zobowiązania UE, pod koniec 2006 roku pojawiła się druga propozycja ustawy antydyskryminacyjnej, która została przedłożona Sejmowi 12 lipca 2007 roku. Na trzecim czytaniu w dniu 19 marca 2008 r. projekt ten został uchwalony z pewnymi poprawkami. W dniu 31 marca 2008 r. ustawa antydyskryminacyjna zatwierdzona przez Sejm została doręczona do Senatu (nr 225). ${ }^{79}$ Projektowi udało się uzyskać zgodę Senatu, jednak 3 czerwca 2008 r. zawetował go były prezydent RCZ Václav Klaus. Dopiero 17 czerwca

74 Art. 16 ust. 2 kodeksu pracy: „W stosunkach pracy zakazana jest jakakolwiek dyskryminacja. Pojęcia dyskryminacji bezpośredniej i pośredniej, molestowania, (...) nakładania do dyskryminacji oraz określenie sytuacji, kiedy dyskryminacja jest dozwolona, reguluje ustawa antydyskryminacyjna."

75 O. Dvorská, Evropský rok rovných př́ležitostí a implementace směrnic Rady 2000/43/ES a 2000/78/ES, Brno 2011, s. 10.

76 Předpis č. 198/2009 Sb. Zákon o rovném zacházení a o právních prostředcích ochrany před diskriminací a o změně některých zákonů (antidiskriminační zákon), z dnia 23 kwietnia 2009 r., obowiązuje od 29 czerwca 2009 r.

77 Na podst. art. 2 ust. 4 do podstaw dyskryminacji dodano dyskryminację na podstawie ciąży, macierzyństwa, ojcostwa, identyfikacji płciowej.

78 Art. 1 ust. 4 kodeksu pracy, zakoník práce č. 65/1965 Sb., obowiązywał od 1 stycznia 1966 do 31 grudnia $2006 \mathrm{r}$.

79 O. Dvorská, op. cit., s. 11.

Prawo 320, 2016

(C) for this edition by CNS 
2009 r. Senat przegłosował veto prezydenta i podjął uchwałę o przyjęciu ustawy antydyskryminacyjnej. W dniu 20 lipca 2009 r. ustawa antydyskryminacyjna ${ }^{80}$ została opublikowana w Dzienniku ustaw (zbírka zákonů) pod numerem 198/2009 Sb. Ustawa weszła w życie 1 września 2009 r., jednak postanowienia dotyczące Rzecznika Praw Obywatelskich, który jest organem antydyskryminacyjnym, weszły w życie dopiero 1 grudnia 2009 roku $^{81}$. Republika Czeska jako ostatnia z państw członkowskich UE przyjęła ogólną ustawę antydyskryminacyjną.

\section{Ustawa antydyskryminacyjna oraz kodeks pracy jako źródło ochrony przed dyskryminacją}

Ustawa antydyskryminacyjna w Republice Czeskiej jest najważniejszym i najogólniejszym aktem prawa wewnętrznego regulującym prawo do równego traktowania oraz ochronę przed dyskryminacją. Jej podstawą są międzynarodowe akty prawne, które były przedmiotem implementacji do porządku prawnego RCZ w 2000 r. Celem ustawy jest zapewnienie sprawiedliwości społecznej, równych szans, które są podstawą pełnego wykorzystania zasobów ludzkich oraz rozwoju społeczeństwa ${ }^{82}$. Ustawa ta definiuje podstawowe pojęcia i identyfikuje, w jakich obszarach i z jakiego powodu dyskryminacja jest zakazana. Ustanawia również wyjątki od zasady równego traktowania, określa sposoby ochrony przed dyskryminacją i nadaje uprawnienia Rzecznikowi Praw Obywatelskich w zakresie równego traktowania.

Podstawowe prawo podmiotowe osoby fizycznej do równego traktowania w katalogu sytuacji prawnych ${ }^{83}$ zostało zawarte w art. 1 ust. 3 ustawy antydyskryminacyjnej. $Z$ prawa do równego traktowania na podstawie ustawy dyskryminacyjnej zostały więc wyłączone osoby prawne. Prawo do równego traktowania na podstawie ustawy oznacza prawo do dyskryminacji na podstawie powodów określonych w ustawie. Dyskryminacja została dalej podzielona modelowo na dyskryminację bezpośrednią ${ }^{84}$ oraz pośrednią. Do dyskryminacji zaliczono rów-

80 Zákon o rovném zacházení a o právních prostředcích ochrany před diskriminací (antidiskriminační zákon).

$81 \mathrm{http}: / /$ lidskaprava.poradna-prava.cz/antidiskriminacni-zakon/prijimani-antidiskriminacnihozakona.html (dostęp: 20.10.2015).

82 J. Jakubka, Nový antidiskriminační zákon a jeho aplikace v pracovněprávních vztazích, „Práce a mzda” 2009, č. 9.

83 Do sytuacji prawnych chronionych przed dyskryminacją zaliczamy dostęp do zatrudnienia, działalności gospodarczej, stosunku w zatrudnieniu, ubezpieczenia socjalnego, dostęp do opieki zdrowotnej, uczestnictwo w związkach zawodowych.

${ }^{84}$ Dyskryminacja bezpośrednia rozumiana jest jako sytuacja, w której osoba w szczególności ze względu na płeć, rasę, pochodzenie etniczne, narodowość, religię, wyznanie, światopogląd, niepełnosprawność, wiek, orientację seksualną, tożsamość płciową lub ekspresję płciową jest 
nież molestowanie, molestowanie seksualne, wiktymizację, nakłanianie oraz podżeganie do dyskryminacji. Dodatkowo do dyskryminacji należą przypadki mniej korzystnego traktowania osoby na podstawie nie tylko rzeczywistej, ale również domniemanej/rzekomej przyczyny dyskryminacji — dyskryminacja przez asumpcję $^{85}$. Taka sytuacja nastąpi, kiedy np. pracodawca błędnie domniemywa przynależność potencjalnego pracownika do dyskryminowanej grupy (np. mniejszość narodowa), co spowoduje nieprzyjęcie pracownika na dane stanowisko (które uzyska osoba o mniejszych kwalifikacjach). W przypadku dyskryminacji pośredniej ${ }^{86}$ została dopuszczona pewna dysproporcja (dopuszczalne odmienne traktowanie) ze względu na zgodny z prawem cel, brak jest jednak chociaż przykładowego katalogu takich przypadków.

Artykuł 6 ustawy przedstawia przypadki dopuszczalnego odmiennego traktowania ze względu na wiek (w szczególności wymóg doświadczenia czy praktyki, minimalnego wieku, jeżeli jest to warunek konieczny dla prawidłowego wykonywania zawodu). Odmienne traktowanie jest również możliwe w pewnych sytuacjach pracowniczych ${ }^{87}$, sytuacjach związanych z kościołami i związkami wyznaniowymi oraz sytuacjach ochrony kobiet w ciąży, w macierzyństwie, osób niepełnosprawnych oraz osób niepełnoletnich.

Należy określić również stosunek ustawy antydyskryminacyjnej do nowego kodeksu pracy. Nowy kodeks pracy w swoich artykułach zajmujących się równym traktowaniem oraz zakazem dyskryminacji $\mathrm{w}$ stosunkach pracowniczych (art. 16 i $17 \mathrm{KP}$ ) odsyła w kwestiach definicji oraz środkach ochrony prawnej przed dyskryminacją do przepisów ustawy antydyskryminacyjnej ${ }^{88}$. Porównując jednak zakres powodów dyskryminacyjnych, KP oraz ustawa antydyskryminacyjna znacząco się różnią. W ustawie antydyskryminacyjnej ustalono zamknięty katalog przyczyn dyskryminacji, natomiast w KP w art. 16 zakazano wszelkiej dyskryminacji, bez odesłania do ustawy antydyskryminacyjnej. W realnych stosunkach pracowniczych w Republice Czeskiej sytuacje dyskryminacji są znacznie bardziej zróżnicowane i pojawiają się przypadki dyskryminacji nienależące do ośmiu przyczyn dyskryminacji ustalonych w ustawie antydyskryminacyjnej.

traktowana mniej korzystnie niż jest, była lub byłaby traktowana inna osoba w porównywalnej sytuacji. Do dyskryminacji ze względu na płeć zaliczamy również dyskryminację ze wzgędu na ciążę, macierzyństwo, ojcostwo i identyfikację płciową — art. 2 ustawy antydyskryminacyjnej.

85 Art. 2 ust. 5 ustawy antydyskryminacyjnej.

${ }^{86}$ Dyskryminacja pośrednia to sytuacja, w której ze względów takich jak w dyskryminacji bezpośredniej na skutek pozornie neutralnego postanowienia, zastosowanego kryterium lub podjętego działania występują lub mogłyby wystąpić niekorzystne dysproporcje lub szczególnie niekorzystna dla osoby sytuacja, chyba że postanowienie, kryterium lub działanie jest obiektywnie uzasadnione ze względu na zgodny z prawem cel, który ma być osiągnięty, a środki służące osiągnięciu tego celu są właściwe i konieczne.

${ }^{87}$ Odmienne traktowanie jest możliwe, jeżeli powód nierówności oparty jest o charakter wykonywanej pracy i zachowa wymóg proporcjonalności.

88 M. Vysokajová et al., Zákoník práce, Komentár, Praha 2013, s. 23. 
Znaczna liczba pracowników ${ }^{89}$ jest dyskryminowana nie z powodów takich jak rasa czy wiek, ale $\mathrm{z}$ bardziej powszednich powodów takich, jak brak sympatii między pracodawcą i pracownikiem, pracownik w przeszłości domagał się swoich praw, przedstawianie swoich profesjonalnych opinii przez pracownika, ochrona swojego stanowiska w przypadku bezsensownych zadań w pracy. Przed takimi przejawami dyskryminacji nie chroni jednak ustawa antydyskryminacyjna. Pracownicy dyskryminowani są skazani w takich przypadkach na zwykłe postępowanie cywilne, znajdują się więc w utrudnionej sytuacji dowodowej, ponieważ nie mogą skorzystać z rozkładu ciężaru dowodu. Wyjątek od zasady, że ciężar dowodu (wykazania istnienia przesłanek faktycznych) spoczywa na osobie, która wywodzi z nich skutki prawne, ma zastosowanie wyłącznie w sytuacjach określonych w ustawie antydyskryminacyjnej ${ }^{90}$.

\section{Wnioski}

Analiza dorobku UE dotyczącego zasady równości pozwala wysunąć wniosek, iż ostatnie kilka lat przyniosło zmiany w odniesieniu do zasady niedyskryminacji uznawanej za podstawowe prawo człowieka. Najważniejszym unijnym instrumentem prawnym $\mathrm{w}$ walce $\mathrm{z}$ dyskryminacją są dyrektywy, które unijny ustawodawca konsekwentnie wykorzystuje w celu nadania państwom członkowskim narzędzi do walki z dyskryminacją. Trybunał Sprawiedliwości UE poświęcił także kwestii dyskryminacji dużo uwagi, liczne orzecznictwo powstało szczególnie $\mathrm{w}$ zakresie równego traktowania kobiet i mężczyzn. W praktyce można znaleźć przypadki bezsilności osób dyskryminowanych spowodowanej często niską świadomością społeczną obywateli ${ }^{91}$. Jednak całość dorobku unijnego oraz krajowego ustala wszechstronny oraz dynamicznie się rozwijający system walki $\mathrm{z}$ dyskryminacją.

W Republice Czeskiej ${ }^{92}$ formalne wymogi prawne, gwarancje instytucjonalne i prawne zakazu dyskryminacji w stosunkach pracy są obecnie na stosunkowo dobrym poziomie. W pierwszej kolejności Karta RCZ gwarantuje zakaz dyskryminacji. Zasada równego traktowania oraz niedyskryminacji w ostatnich latach rozwijała się w RCZ pod presją UE. Pomimo przeszkód politycznych, które towarzyszyły ustawie antydyskryminacyjnej, ostatecznie udało się, podjęto uchwałę o jej przyjęciu. Ustawa ta spełnia wymogi unijne. Pomimo pewnych niedocią-

89 Dyskryminacja pojawia się w zakresie warunków pracy, wynagrodzenia itp.

90 D. Brůha, Praktické problémy antidiskriminačního zákona (z pohledu zaměstnance), výklady, 2010, http://www.danarionline.cz/archiv/dokument/doc-d8379v11040-prakticke-problemyantidiskriminacniho-zakona-z-pohledu/ (dostęp: 20.10.2015).

91 W 2008 r. wpłynęło do Komisji w sprawie dyskryminacji Polaków przez niemieckie Urzędy ds. Młodzieży ok. 200 petycji.

92 Republika Czeska jest państwem członkowskim UE od 1 maja 2004 roku. 
gnięć (brak jedności, powielanie przepisów), czeskie przepisy antydyskryminacyjne w dziedzinie prawa pracy można ocenić pozytywnie. Niezależnie od zmian w prawie pracy, dyskryminacja pojawia się nadal często w stosunkach pracy. Przyczyną nierówności osób lub grup są często stereotypy społeczeństwa, co do istoty dyskryminacja jest problemem socjalnym. Z raportu ${ }^{93} \mathrm{z}$ działalności Państwowej Inspekcji Pracy za rok 2014 wynika, że w przestrzeganiu obowiązku równego traktowania i niedyskryminacji pojawiają się liczne ${ }^{94}$ braki w kontrolowanych jednostkach, jednak ilość kar finansowych obciążających te jednostki jest niewysoka $^{95}$. Niepożądany jest również fakt, iż sądownictwo czeskie rzadko przyznaje dyskryminowanemu rekompensatę finansową, co jest niezgodne $\mathrm{z}$ orzecznictwem TSUE ${ }^{96 .}$ Częściej pojawiają się wyroki sądów czeskich przyznające rekompensatę finansową w sprawach karnych ${ }^{97}$. Pod względem faktycznego ograniczenia dyskryminacji w stosunkach pracy Republika Czeska nie należy więc jeszcze do bardziej postępowych państw członkowskich $\mathrm{UE}^{98}$.

\section{Adaptation of domestic law in the Czech Republic to the EU anti-discrimination requirements based on the example of labor law}

\section{Summary}

This article deals with one of the most crucial fields of EU social policy, namely with the principle of non-discrimination and its transposition into Czech national law. The degree of implementation varies greatly between the countries. The purpose of this article is to present the example of law implementation in the EU and highlight some specific issues of concern relating to the state of the adoption of EU anti-discrimination directives.

Keywords: implemenation of EU law, discrimination, Czech national law, labour law, Court of Justice.

93 Státní úřad inspekce práce, Zpráva o činnosti Státního úŕadu inspekce práce za rok 2014, http://www.suip.cz/_files/suip-bb053aaca38eef09e4c5081782ebcbfd/zprava_o_cinnosti_2014.pdf. (dostęp: 20.10.2015).

94 Artykuł 4 ustawy č 435/2004 Sb. o zaměstanosti (o zatrudnieniu), określający zakaz jakiejkolwiek dyskryminacji w związku z prawem do zatrudnienia, został naruszony 76 razy. Artykuł 12 tej ustawy, ustalający zakaz dyskryminacji w ofercie pracy, został naruszony 52 razy.

95 Nałożono 16 kar finansowych, łącznie w wysokości 134 tys. koron czeskich.

96 P. Boučková et al., Antidiskriminační zákon. Komentář Praha 2010, s. 298.

97 Przykładem jest orzeczenie sądu okręgowego RCZ w Ostawie w sprawie ataku podpalaczy na romski dom rodzinny (Rozsudek Krajského soudu v Ostravě sp. zn. 32T 2/2010-4163 ze dne 20.10.2010, http://portal.justice.cz/justice2/soud/soud.aspx $? \mathrm{o}=19 \& \mathrm{j}=29 \& \mathrm{k}=337 \& \mathrm{~d}=314740$.) (dostęp: 20.10.2015). Osoby odpowiedzialne za czyn skazane zostały na 20 do 22 lat więzienia oraz osobie pokrzywdzonej przyznano prawie $10 \mathrm{mln}$ koron czeskich (około 413 tys. euro).

$98 \mathrm{http}: / /$ ec.europa.eu/justice/discrimination/files/antidiscrimination_law_review_12_en.pdf (dostęp: 20.10.2015). 


\section{Bibliografia}

Agencja Praw Podstawowych, Rada Europy, Podręcznik europejskiego prawa o niedyskryminacji, Urząd Publikacji Unii Europejskiej, 2011.

Błachnio-Parzych A. et al., Karta Praw Podstawowych Unii Europejskiej. Komentarz, Warszawa 2012.

Bojarski Ł. et al., Karta Praw Podstawowych Unii Europejskiej jako żywy instrument, Podręcznik dla prawników, Warszawa 2014.

Boučková P. et al., Antidiskriminační zákon. Komentář, Praha 2010.

Brůha D., Praktické problémy antidiskriminačního zákona (z pohledu zaměstnance), výklady, 2010. http://www.mzdovapraxe.cz/archiv/dokument/doc-d8379v11040-prakticke-problemy-antidiskriminacniho-zakona-z-pohledu-zame/?search_query $=\$$ source $=3 \% 20 \$$ issue $=3195$

Český Krumlov ve spolupráci s Českým helsinským výborem, Soudní praxe v oblasti diskriminace na trhu práce. Analýza judikatury Evropské unie a českých soudü, Český Krumlov 2008.

Dandová E., Zákonik práce a EU: V otázkách a odpovédích, Praha 2004.

Dvorská O., Evropský rok rovných přiležitostí a implementace směrnic Rady 2000/43/ES a 2000/78/ ES, Brno 2011.

Farkas L., European Commision, Directorate-General for Justice, How to Present a Discrimination Claim: Handbook on seeking remedies under the EU Non-discrimination Directives, UE 2011. Forejtová M., Výjimky z Listiny základních práv EU pro ČR?, Právní Prostor, 2014.

Galewska E., Implementacja dyrektyw telekomunikacyjnych, Kraków 2007.

Jakubka J., Nový antidiskriminační zákon a jeho aplikace v pracovněprávních vztazích, „Práce a mzda" 2009, č. 9. http://www.mzdovapraxe.cz/archiv/dokument/doc-d5585v7714-novy-antidiskriminacni-zakon-a-jeho-aplikace-v-pracovnepravnich/ (dostęp: 10.10.2015).

Kałwak W., Przewodnik po prawie Unii Europejskiej, Warszawa 2010.

Kędziora K., Śmiszek K., Dyskryminacja i mobbing w zatrudnieniu, Warszawa 2003.

Kędziora K., Śmiszek K., Wybrane orzecznictwo sądów krajowych i międzynarodowych w sprawach o dyskryminacje, Warszawa 2013.

Komisja Europejska, Równość: przepisy UE dotyczace przeciwdziałania dyskryminacji obowiąuja teraz we wszystkich 28 państwach UE (komunikat prasowy), Bruksela 2014.

Kurcz B., Dyrektywy Wspólnoty Europejskiej i ich implementacja do prawa krajowego, Kraków 2004.

Kurcz B., Harmonisation by means of Directives - never-ending story, „Europen Bussiness Law Rewiev" 2001, nr 11-12.

Matlochová E., Uprawnienia polskiej mniejszości narodowej w Republice Czeskiej, "Folia Iuridica Wratislaviensis" vol. 2, 2013, nr 2, Wrocław, 2013.

Mik C., Europejskie prawo wspólnotowe. Zagadnienia teorii i praktyki, t. 1, Warszawa 2000.

Mitrus L., Rozwój prawa wspólnotowego w dziedzinie równego traktowania kobiet i mężczyzn w zatrudnieniu, Warszawa 2007.

Nowicki, M.A., Opinia dla Komisji Spraw Zagranicznych i Integracji Europejskiej Senatu Rzeczypospolitej Polskiej na temat Karty Praw Podstawowych UE, www.hrpol.waw.pl/index-pliki/ karta/OpiniaMAN.htm.

Pavlíček V. et al., Ústavni právo a státověda,t. 2, Ústavní právo České republiky, Praha 2011.

Pomaska A., Opinia w sprawie sprawozdania Komisji dla Parlamentu Europejskiego i Rady z dnia 5 lipca 2006 r. w sprawie wprowadzenia w życie zasady równości szans oraz równego traktowania kobiet i mężczyzn dziedzinie zatrudnienia i pracy (wersja przeredagowana), Warszawa 2014.

Urząd Publikacji Unii Europejskiej, Sprawozdanie z działalności w latach 2007 i 2008, Luksemburg 2009.

Prawo 320, 2016

(C) for this edition by CNS 
Traktat o funkcjonowaniu Unii Europejskiej. Komentarz, t. 1, red. D. Miąsik, N. Półtorak, A. Wróbel, Warszawa 2012.

Vysokajová M. et al., Zákoník práce, Komentář, Praha 2013.

Wawrowski Ł., Polityka równych szans. Instytucjonalne mechanizmy zwiększania partycypacji kobiet w strukturach politycznych na przykładzie państw Unii Europejskiej, Torun 2007.

Zemanová Šimanová H., Soudni prostředky ochrany před diskriminací v pracovněprávních vztazích, Brno 2010.

\section{Wykaz aktów prawnych}

Traktat o funkcjonowaniu Unii Europejskiej, Dz.U. C 326 z dnia 26 października 2012 r.

Traktat z Lizbony zmieniający Traktat o Unii Europejskiej i Traktat ustanawiający Wspólnotę Europejską, sporządzony w Lizbonie dnia 13 grudnia 2007 r., Dz.U. z 2009 r. Nr 203, poz. 1569.

P1.ÚS 19/08 z dnia 26 listopada 2008 r., 446/2008 Sb.

Pl.ÚS 36/01 z dnia 25 czerwca 2002, 403/2002 Sb. N 80/26 SbNU 317.

Traktat z Amsterdamu zmieniający Traktat o Unii Europejskiej, traktaty ustanawiające Wspólnoty Europejskie i niektóre związane z nimi akty (tzw. Traktat Amsterdamski) — podpisany 2 października 1997 r. (wszedł w życie 1 maja 1999 r.) — Dz.U. z 2004 r. Nr 90, poz. 864/31.

Dyrektywa 75/117/EWG w sprawie zbliżenia ustawodawstw Państw Członkowskich dotyczących stosowania zasady równości wynagrodzeń dla kobiet i mężczyzn, Dz.U. nr L 45 z 19.2.1975.

Dyrektywa rady 2004/113/WE z dnia 13 grudnia 2004 , Dz.U. UE L 373 z 21.12.2004.

Dyrektywa 2006/54/WE Parlamentu Europejskiego i Rady z dnia 5 lipca 2006 r. w sprawie wprowadzenia w życie zasady równości szans oraz równego traktowania kobiet i mężczyzn w dziedzinie zatrudnienia i pracy, Dz.U. UE L 204 z 26.7.2006

Decyzja nr 771/2006/WE Parlamentu Europejskiego i Rady z dnia 17 maja 2006 r. ustanawiająca Europejski Rok na rzecz Równych Szans dla Wszystkich (2007) — w Kierunku Sprawiedliwego Społeczeństwa, Dz.U. L 1146, 31/05/2006P. 0001-0007

Stanowisko Parlamentu Europejskiego przyjęte w pierwszym czytaniu w dniu 13 grudnia 2005 r. w celu przyjęcia decyzji nr 1600/2002/WE(4)/2006/WE Parlamentu Europejskiego i Rady w sprawie Europejskiego Roku na rzecz Równych Szans dla Wszystkich (2007) — W kierunku sprawiedliwego społeczeństwa

Sprawa 14/83 mająca za przedmiot skierowany do Trybunału, na podstawie art. 177 traktatu EWG, przez Arbeitsgericht w Hamm wniosek o wydanie, w ramach zawisłego przed tym sądem sporu między Sabine von Colson i Elisabeth Kamann a Land Nordrhein-Westfalen, orzeczenia w trybie prejudycjalnym w sprawie wykładni dyrektywy Rady nr 76/207 z dnia 9 lutego 1976 r. w sprawie wprowadzenia w życie zasady równego traktowania kobiet i mężczyzn w zakresie dostępu do zatrudnienia, kształcenia i awansu zawodowego oraz warunków pracy (Dz.U. L 39, s. 40).

LI:EU:C:1997:208

Ústavá České republiky, ústavní zákon č. 1/1993. Sb., uchwalona przez Czeską Radą Narodową dnia 16 grudnia $1992 \mathrm{r}$.

Listina základních práv a svobod, przyjęta jeszcze w czasie istnienia Czechosłowacji 9 stycznia 1991 r., na mocy ustawy č.23/1991 Sb.

Zákon o zaměstnanosti z dnia 13 maja 2004 r., z późn. zm., č. 435/2004 Sb.

Zákoník práce, z dnia 21 kwietnia 2006 r., obowiązuje od 1 stycznia 2007 roku, č. 262/2006 Sb.

Občanský zakoník z dnia 3 lutego 2012 r., č. 89/2012Sb.

Zakoník prace č. 65/1965.

Zákon č. 155/2000 Sb.

Zákon č. 46/2004 Sb.

Prawo 320, 2016

(C) for this edition by CNS 
Předpis č. 198/2009 Sb. Zákon o rovném zacházení a o právních prostředcích ochrany před diskriminací a o změně některých zákonů (antidiskriminační zákon)

\section{Wykaz źródeł internetowych}

http://www.sejm.gov.pl/Sejm7.nsf/InterpelacjaTresc.xsp?key=440B1ED5

http://www.pravniprostor.cz/clanky/mezinarodni-a-evropske-pravo/vyjimky-z-listiny-zakladnich-prav-eu-pro-cr

http://rownetraktowanie.gov.pl/dyskryminacja-ze-wzgledu-na-plec

$\mathrm{http} / / /$ ec.europa.eu/justice/discrimination/index_pl.htm

http://lidskaprava.poradna-prava.cz/antidiskriminacni-zakon/prijimani-antidiskriminacniho-zakona.html

http://www.danarionline.cz/archiv/dokument/doc-d8379v11040-prakticke-problemy-antidiskriminacniho-zakona-z-pohledu/

http://curia.europa.eu/arrets/TRA-DOC-PL-ARRET-C-0014-1983-200407000-05_02.html

http://www.mzdovapraxe.cz/archiv/dokument/doc-d8379v11040-prakticke-problemy-antidiskriminacniho-zakona-z-pohledu-zame $/$ ?search query $=\$$ source $=3 \% 20 \$$ issue $=3$ I 95

http://www.mzdovapraxe.cz/archiv/dokument/doc-d5585v7714-novy-antidiskriminacni-zakon-ajeho-aplikace-v-pracovnepravnich/ 